\title{
Network dynamics of encoding and retrieval of behavioural spike sequences during theta and ripples in a CA1 model of the hippocampus
}

\author{
Vassilis Cutsuridis, Michael Hasselmo \\ From Nineteenth Annual Computational Neuroscience Meeting: CNS*2010 \\ San Antonio, TX, USA. 24-30 July 2010
}

Spatial memory in the hippocampus is encoded and retrieved by the firing frequency and spike timing of pyramidal cells and inhibitory interneurons during network oscillations. Theta oscillations $(4-10 \mathrm{~Hz})$ are observed in rats during exploration and rapid eye movement (REM) sleep, whereas sharp wave-associated ripples (100-200 Hz) are observed during slow-wave sleep (SWS) and consummatory behaviours. Hippocampal theta rhythm has been suggested to contribute to memory formation by separating encoding and retrieval into functional sub-cycles [1]. On the other hand, ripple activity has been demonstrated to structure temporally compressed forward and reverse replay of waking neuronal activity [2-4]. Recent experimental studies have shown that different CA1 excitatory and inhibitory neurons fire at different phases of the theta and ripple rhythms [5-7]. Similarly, medial septal GABAergic neurons differentially phase their activities with respect to theta and ripple $[8,9]$.

We investigate, via computer simulations, the biophysical mechanisms by which storage and recall of behavioural spike sequences are achieved by the CA1 microcircuitry. A model of the CA1 microcircuit [10-12] is extended that uses biophysical representations of the major cell types, including pyramidal $(\mathrm{P})$ cells and five types of inhibitory interneurons: basket (B) cells, axoaxonic (AA) cells, bistratified (BS) cells, IVY cells and oriens lacunosum-moleculare (OLM) cells. Inputs to the network come from the entorhinal cortex (EC), the CA3 Schaffer collaterals and medial septum.

Our model addresses two important issues: (1) How are encoding and replay (forward and reverse) of behavioural place sequences controlled in the CA1 microcircuit during theta and ripples? (2) What roles do the various types of inhibitory interneurons play in these encoding and retrieval processes?

\section{Acknowledgement}

This work is funded by the NSF Science of Learning Centre CELEST SBE0354378.

\section{Published: 20 July 2010}

\section{References}

1. Hasselmo M, Bodelon C, Wyble B: A proposed function of the hippocampal theta rhythm: Separate phases of encoding and retrieval enhance reversal of prior learning. Neural Comput 2002, 14:793-817.

2. Buzsaki G: Two-stage model of memory trace formation: a role for "noisy" brain states. Neuroscience 1989, 31(3):551-570.

3. Diba K, Buzsaki G: Forward and reverse hippocampal place-cell sequences during ripples. Nat Neurosci 2007, 10(10):1241-42.

4. Foster DJ, Wilson MA: Reverse replay of behavioural sequences in hippocampal place cells during the awake state. Nature 2006, 440:680-83.

5. Fuentealba P, Begum R, Capogna M, Jinno S, Marton LF, Csicsvari J, Thomson A, Somogyi P, Klausberger T: Ivy cells: a population of nitricoxide-producing slow-spiking GABAergic neurons and their involvement in hippocampal network activity. Neuron 2008, 57:917-929.

6. Klausberger T, Magill PJ, Marton LF, Roberts JDB, Gobden PM, Buzsaki G, Somogyi P: Brain-state and cell-type-specific firing of the hippocampal interneurons in vivo. Nature 2003, 421:844-48.

7. Klausberger T, Marton LF, Baude A, Roberts JDB, Magill PJ, Somogyi P: Spike timing of dendrite-targeting bistratified cells during hippocampal network oscillations in vivo. Nat Neurosci 2004, 7(1):41-47.

8. Borhegyi Z, Varga V, Szilagyi N, Fabo D, Freund TF: Phase segregation of medial septal GABAergic neurons during hippocampal theta activity. J Neurosci 2004, 24(39):8470-79.

9. Dragoi G, Carpi D, Recce M, Csicsvari J, Buzsaki G: Interactions between hippocampus and medial septum during sharp waves and theta oscillation in the behaving rat. J Neurosci 1999, 19(14):6191-99.

10. Cutsuridis V, Cobb S, Graham BP: Encoding and Retrieval in a CA1 Microcircuit Model of the Hippocampus. ICANN 2008, LNCS 5164, (SpringerVerlag Berlin Heidelberg 2008) V. Kurkova, R. Neruda, and J. Koutnik 2008, 238-247.

\footnotetext{
* Correspondence: vcut@bu.edu

Centre for Memory and Brain, Boston University, Boston, MA, USA
} 
11. Cutsuridis V, Cobb S, Graham BP: Encoding and retrieval in the hippocampal CA1 microcircuit model. Hippocampus 2009.

12. Cutsuridis V, Wenneckers T: Hippocampus, microcircuits and associative memory. Neural Networks 2009, 22(8):1120-8.

doi:10.1186/1471-2202-11-S1-P55

Cite this article as: Cutsuridis and Hasselmo: Network dynamics of encoding and retrieval of behavioural spike sequences during theta and ripples in a CA1 model of the hippocampus. BMC Neuroscience 2010 11(Suppl 1):P55.

Submit your next manuscript to BioMed Central and take full advantage of:

- Convenient online submission

- Thorough peer review

- No space constraints or color figure charges

- Immediate publication on acceptance

- Inclusion in PubMed, CAS, Scopus and Google Scholar

- Research which is freely available for redistribution

Submit your manuscript at www.biomedcentral.com/submit
C Biomed Central 